\title{
«Національна книга пам’яті жертв Голодомору 1932-1933 рр. Дніпропетровська область»: соціально-демографічний аналіз
}

\author{
Хоменко Н.О., Дніпровський національний університет ім. Олеся Гончара
}

Проаналізовано стан вивчення проблеми кількісних втрат від Голодомору 1932-1933 рр. у Дніпропетровській області. Виявлено, що мається обмежене коло досліджень 3 даної проблематики. У своїй більшості вони присвячені висвітленню конкретної ситуації в селах області. Лише в окремих із них зроблена спроба аналізу демографічних наслідків Голодомору. Практично невідомими залишаються втрати населення в кожній іiі адміністративній одиниці як загалом, так і в соціальному, статевому, національному, віковому аспектах зокрема. В якості предмета дослідження обрано загальноукраїнський археографічний збірник, який складений на основі матеріалів книг записів цивільного стану населення, і єдиний на сьогодні в Україні містить зафіксовані свідчення про померлих, «Національна книга пам’яті жертв голодомору 1932-1933 pp. Дніпропетровська область». У ході дослідження було виявлено, що загальноукраїнські тенденції він відображає. При цьому містить і ряд особливостей. За вміщеними в ньому матеріалами більшість померлих в області становило міське населення. В містах найбільшу категорію загиблих складають робітники. Другою соціальною категорією померлих були селяни. Службовці були на третьому місці. В селах проживали також робітники і вони становили другу, хоч і значно меншу порівняно з селянами, категорію померлих. За національним складом більшість жертв Голодомору становили українці, потім росіяни, на третьому місці були євреї. Проте в місцях компактного проживання представників якоїсь із національностей більшість була за ними. У графі про причину смерті відносну більшість, порівняно з записами видів діагнозів, і в містах, і в сільській місцевості становили пробіли. Значним був відсоток діагнозів, що непрямо, але вказували причиною летального випадку голод. Виявлено і декілька десятків записів про голод як безпосередню причину трагічного факту.

Ключові слова: Голодомор 1930-х рр., «Національна книга пам’яті жертв Голодомору», Дніпропетровська область, Голод 1932-1933 рр. на селі, місто в умовах Голодомору, терор голодом, демографічні наслідки Голодомору

\section{«National Book of Memory of Victims of the Holodomor 1932-1933 Dnipropetrovsk Region»: socio-demographic analysis}

\section{Khomenko N.A., Oles Honchar Dnipro National University}

The state of study of problem of quantitative losses is analysed from Golodomor 1932-1933 in the Dnepropetrovsk area. It is educed that a limit circle of researches is from this range of problems. In the majority they are sanctified to illumination of certain situation in rural locality of area in general. A city in general remained out of eyeshot researchers. Only in separate publications the done attempt of analysis of demographic consequences of terror-famine in general for areas. Practically the unknown are remained by the losses of population in each her to administrative unit both on the whole and in social, sexual, national, age-old aspects, in particular. As the article of research all Ukrainian archaeography collection that is made on the basis of materials of books of records of the civil state of population is select, and only for today in Ukraine contains the fixed testifying to the dead, «National book of memory of victims of terror-famine 1932-1933 the Dnepropetrovsk area». It was educed during research, that Book of memory is made on the basis of books of acts of the civil state of population rural inhabited points, settlement, municipal and in the cities of district soviets. All of them contain the necessary complex of data about lost: year of birth, eyelids, sex, nationality, social state, date and reason of death. The table of contents of her represents all Ukrainian tendencies. The row of features contains thus. Main is that information that is contained in her, is incomplete. In the first turn, on the presence of books of acts of the civil state, that she is folded. In general materials failing on the row of that time districts. After the materials contained in her the most in area of dead was presented by an urban population. It can be explained by the best stored of books to civil registration their population. In cities the most category of lost is folded by workers. The second social category of the dead were peasants. Office workers were on the third place. In villages, workers lived also and they presented the second, though considerably less comparatively with peasants, category of the dead. The analysis of book showed that after national composition most victims of terror-famine were presented by Ukrainians, as prevailing part of population of republic, then Russians, there were jewries on the third place. The row of features contains thus. Main is that information that is contained in her, is incomplete. In the first turn, on the presence of books of acts of the civil state, that she is folded. In general materials failing on the row of that time districts. After the materials contained in her the most in area of dead was presented by an urban population. It can be explained by the best stored of books to civil registration their population. In cities the most category of lost is folded by workers. The second social category of the dead 
were peasants. Office workers were on the third place. In villages, workers lived also and they presented the second, though considerably less comparatively with peasants, category of the dead. The analysis of book showed that after national composition most victims of Golodomor were presented by Ukrainians, as prevailing part of population of republic, then Russians, there were jewries on the third place.

Keywords: Terror-famine of 1930th, «National book of memory of victims of Terror-famine», Dnipropetrovs'k area, Hunger 1932-1933 on a village, city in the conditions of Terror-famine, terror hunger, demographic consequences of Terror-famine

\section{«Национальная книга памяти жертв Голодомора 1932-1933 гг. Днепропетровская область»: социально-демографический анализ}

\section{Хоменко Н.А., Днепровский национальный университет им. Олеся Гончара}

Проанализирована историографическая ситуация в изучении проблемы количественных потерь в Днепропетровской области. Выявлено, что имеется

ограниченный круг работ по данной проблематике. В своем большинстве они посвящены рассмотрению конкретной ситуации в селах области. Лишь в отдельных из них сделаны попытки анализа демографических последствий Голодомора. Практически неизвестными остаются потери населения в каждой ее административной единице как вообще, так и в социальном, национальном, возрастном аспектах в частности. В качестве предмета исследования избран общеукраинский археографический сборник, который составлен на основании книг актов гражданского состояния, и единственный в Украине на сегодня содержит зафиксированные сведения об умерших, «Національна книга пам’яті жертв Голодомору 1932-1933 рр. Дніпропетровська область» В ходе исследования было выявлено, что общеукраинские тенденции он отражает. При этом содержит и ряд особенностей. По содержащимся в нем материалам большинство среди погибших в области составили городские жители. В городах наибольшую категорию погибших составляли рабочие. Вторую по численности категорию составляли крестьяне. Служащие были на третьем месте. В селах также проживали рабочие и они составили вторую, хоть и значительно меньшую по сравнению с крестьянами, категорию умерших. По национальному составу большинство жертв Голодомора были украинцами, потом шли русские и на третьем месте - евреи. Однако, в местах компактного проживания представителей какой-то из национальностей большинство было за ними. В графе о причине смерти большинство, относительно любого из диагнозов, составляли пропуски. Значительным был процент диагнозов, которые непрямо, но указывали причиной летального случая голод. Выявлено и несколько десятков записей о голоде как непосредственной причине трагического факта.

Ключевые слова: Голодомор 1930-х гг, «Национальная книга памяти жертв Голодомора», Днепропетровская область, голод 1932-1933 рр. на селе, город в условиях Голодомора, террор голодом, демографические последствия Голодомора

П роблема Голодомору $1930-\mathrm{x} \mathrm{pp,} \mathrm{попри}$ значну історіографію, має ще чимало аспектів, що потребують ретельного дослідження. Один із таких аспектів - це кількість жертв трагедії. Цьому питанню присвячені праці як вітчизняних дослідників, у першу чергу Кульчицького С. В. [5], Марочко В. І. [6],так і зарубіжних: Конквест Р. [4], Мейс Д. [7]. Проте, незважаючи на значний доробок на загальноукраїнському рівні, на регіональному ця проблема не стала предметом прискіпливої уваги дослідників. I хоча в цьому плані мається певне коло наукових праць, воно доволі обмежене і представлене лише роботами істориків Дніпропетровщини Іваненка В. В.[ 3], Нікілєва О. Ф. [9], Романець Н. Р. [10]. Їх праці присвячені висвітленню конкретних подій, що відбувалися в сільській місцевості області, опису конкретних випадків смертності, демографічним втратам в області в цілому, показу тенденцій, що мали місце у перебігу цієї трагедії. Через це на сьогодні маються лише далеко не повні дані про кількість жертв Голодомору по області загалом. Практично, залишаються невідомими втрати населення в кожній іiі адміністративній одиниці як загалом, так і в соціальному, статевому, національному, віковому аспектах зокрема. Існуюча історіографічна ситуація і визначила вибір теми нашого дослідження. Нами зроблена спроба до певної міри заповнити наукову лакуну і на основі аналізу даних «Національної книги пам'яті жертв Голодомору 1932-1933 рр. Дніпропетровська область», яка містить поіменний мартиролог жертв трагедії, здійснити підрахунки як у кількісному, так і в соціально-демографічному вимірі наслідків трагедії як по області в цілому, так і по іiї містах та сільських районах. Для реалізації цієї мети була розроблена спеціальна програма, яка дозволила зробити підрахунки по всіх адміністративних 
одиницях та за вміщеними у супроводжувальних записах про загиблих параметрами.

Сама Книга пам’яті складена на основі книг актів цивільного стану населення сільських населених пунктів, селищних, міських та у містах районних рад. Усі вони містять необхідний комплекс даних про загиблих: рік народження, вік, стать, національність, соціальний стан, дату та причину смерті. Це дозволяє систематизувати і типологізувати за визначеними параметрами ситуацію в області.

Проте особливістю Книги є те, що інформація, яка міститься в ній, є неповною. У першу чергу за наявністю книг актів цивільного стану, що їі складають. Збереглося лише 259 книг по 247 сільських, селищних, районних у містах та міських радах, у той час як на 1933 р. їх нараховувалося 1113 [1, с.6], тобто 22,2\% їх загальної кількості. Взагалі бракує матеріалів по ряду тогочасних районів, а саме Божедарівському (тепер - частина Криничанського), а також по двох сучасних - Апостолівському та Магдалинівському. По деяких районах збереженість документації є вкрай обмеженою. Наприклад, по П'ятихатському району у наявності є матеріали чотирьох сільрад [8, с.914-926], по Криворізькому [8, c.501] - двох, по Софіївському - однієї [8 с.940]. Проте збережений матеріал також не відзначається повнотою. По 65 сільрадах та міських РАЦСах дані $\epsilon$ лише за один із досліджуваних років. Є сільради, де хоч і подаються дані про смертність по всіх селах за обидва роки, проте ця інформація вкрай неповна. Так, наприклад, по Щербатівській сільраді Томаківського р-ну зафіксовано смерть лише трьох людей [8, с. 955].

Обстеження 22 сільрад області, здійснене працівниками Центрального управління народногосподарського обліку (ЦНГО) при Держплані СРСР та представниками ЦНГО УРСР у 1934 р., показало, що книги обліку смертей були повністю заповнені вже в перші місяці 1933 року. Надалі записи робилися в зошитах або на окремих клаптиках паперу, які в силу різних причин, у першу чергу через смерть осіб, що фіксували загиблих, велися невідповідним чином: на окремих папірцях, нерегулрно. Коли ж було видано нові книги (а це були документи суворої звітності, тож видавалися централізовано), ніхто не перевіряв правильність перенесення в них раніше зроблених записів [3, с. 92].

Про неповне фіксування смертей свідчить i лист завідувача Дніпропетровським облздороввідділом Шрайбера від 11 квітня 1933 року до Павлоградського райздоровінспектора, де він вказує на відсутність у цілому ряді сільрад району реєстрації померлих [2, арк. 2].
Особливістю матеріалу, що містить Книга пам'яті, є ще й те, що нерідко інформація про загиблу особу містить не повний комплекс необхідних даних. Часто є відсутніми дані про його вік, рік народження, національність, соціальний стан, причини смерті. Як у комплексі цих складових, так і якоїсь окремої з них. Нерідко замість соціального походження дитини записано їі соціальний стан: робітник, селянин. Інколи записи про померлого є нелогічними. Наприклад: «34 роки, пенсіонер», «8 років, старість». Багато смертельних випадків записано без встановлення особи.

Щодо діагнозу, то у значній масі випадків записувалися захворювання, не пов'язані напряму 3 тогочасною соціально-економічною ситуацією, це - серцеві, легеневі, мозкові, або ж взагалі нічого не писалося. Книга пам'яті жертв Голодомору в області містить лише дані, що збереглися в існуючих на сьогодні книгах запису цивільного стану осіб. Аналізу було піддано саме цей масив інформації.

Загальна кількість жертв, зафіксованих у ній, за нашими підрахунками становить 65 280. Особливістю iii $\epsilon$ те, що кількість померлих у містах перебільшує кількість померлих у сільській місцевості та складає 36872 тис. осіб. У районах кількість померлих складає 28408 тис. осіб. Але це можна пояснити тим, що у містах була краща збереженість книг реєстрації. Найбільша кількість збережених книг по Дніпропетровську -47.

Відомості про соціальний стан також мають свої особливості. В книзі він не вказаний у нашому сучасному тлумаченні. Дані, які там містяться, були узагальнені і об'єднані у такі великі групи, як: «селяни», «робітники», «службовці», «кустарі», «пенсіонери», «утриманці», «безпритульні», «безробітні». Пенсіонери, безробітні та безпритульні зафіксовані лише в містах. У сільській місцевості стан або не вказувався, або вказувався як селянин.

У ході проведеного дослідження виявлено, що в області як у містах, так і в селах гинули представники всіх соціальних категорій. У містах найбільшу категорію загиблих складають робітники - 14485 осіб, або 63,3\% від загиблих там. Тобто, проблеми 3 продовольством суттєво позначилися на людях робітничих професій міста. Слід зауважити, що у містах значну частку померлих складали селяни - 16,8\%. Це була друга за кількістю категорія. Можна припустити, що вони працювали в колгоспах, що функціонували у селах, розташованих на межах міст, як, наприклад, у Дніпропетровську чи Кривому Розі. Найбільша кількість 
селян знаходилась у місті Марганець. Це можна пояснити тим, що на момент 1933 року він ще не набув статусу міста. До інших категорій, які зазнали значних втрат у містах, належать службовці $(6,1 \%)$, утриманці $(5,6 \%)$ та пенсіонери (6,9\%). Такі категорії, як «безпритульні» та «безробітні» становлять значну меншість у складі померлих. Відповідно 0,1\% та 0,5\%. Кустарів також зафіксовано незначний процент $-0,5 \%$.

У сільській місцевості переважну більшість загиблих склали селяни - 23275 осіб. Але в селах були присутні не лише селяни, а й робітники, які йшли працювати на заводи, щоб вижити. Їх відсоток становить 9\% і це переважно на Криворіжжі, де поряд із селами розміщувалися копальні. Невелика кількість серед померлих були службовцями - 79 осіб. Можна припустити, що це працівники державних структур у сільській місцевості та вчителі. В небагатьох випадках у графі «соціальний стан» людям похилого віку зазвичай записували «на утриманні». Таких зафіксовано 1,4\%.

Стосовно національного складу померлих можна сказати, що переважну більшість зафіксованих Книгою пам' яті 28408 загиблих у сільській місцевості складали українці - 94,1\%, оскільки вони становили основну масу сільського населення області. На другому місці були росіяни - 5,2\%. Решта були євреї $(0,1 \%)$, німці $(0,4 \%)$ та представники інших національностей. Проте в тих населених пунктах, де компактно проживали представники інших національностей, основну масу загиблих складали вони.

Так, наприклад, у Веселівській сільраді Синельниківського району з 44 загиблих 36 були німцями, 2 - росіянами, 6 - українцями, в Катеринівській сільраді Солонянського всі загиблі - німці, у с. Кільманстальське Васильківського району з 52 померлих у цей період 40 осіб були німцями, 1 голландецем, 9 українцями. У Новозорінській сільраді Криворізького району 3 24 померлих 15 осіб становили представники єврейської національності [9, с.102]. В Нікопольському та Павлоградському районах мешкало досить багато росіян, тому й кількість померлих, із загальної кількості зафіксованих по районах, у них була більшою: 2051 особа у першому та 4546 - у другому, становили відповідно 18,8\% та 17,3\% при 79,9\% та 82,6\% відповідно померлих українців.

У містах серед померлих також переважали українці -19668 осіб або 79,9 \% загиблих. Представників інших національностей і кількісно, і за питомою вагою було значно більше, ніж на селі. У першу чергу - росіян $(12,9 \%)$. Третьою національ- ністю міста, що найбільше представлена у Книзі пам'яті, були євреї - 4,9\%. Представники інших національностей (а це білоруси, поляки, німці, латиші, грузини, вірмени татари) разом становлять 2,3\%. У Дніпропетровську з загальної кількості 14160 померлих у місті українців зафіксовано $57,7 \%$, росіян - 24,2\%, євреїв - 15,2\%, білоруси становили $-1,1 \%$, поляки - 0,9\%. Серед померлих зафіксовано представників і інших національностей: німців, латишів, грузинів, татар, вірмен тощо. Але їх питома вага становить 0,9\%. У Кам'янському, другому за розмірами і промисловим потенціалом місті області, співвідношення, практично, було аналогічним, тільки третю позицію, на відміну від обласного центру, займали поляки.

Щодо причин смерті, то матеріали Книги пам'яті містять їх найширший спектр. Від абсолютно професійних і загальноприйнятих у медицині до найнеймовірніших, як от «розширення серця», «туберкульоз позвоночника», «хронічний катар кишок», «катар шлунку», «токсичний коліт», «інвагінація кишок», «туберкульоз кишок», «параліч головного мозку», «зараження мозку». Для аналізу нами були обрані ті причини, які найчастіше зустрічаються. Однотипні причини смерті були об'єднані в одну групу. Наприклад, «міокардит», «серцева недостатність», «параліч серця» $\mathrm{i}$ т. п. узагальнили в групу хвороби серця. За таким принципом були сформовані й інші. Загалом, хвороби об'єднані у 25 груп. Підрахунки за цією складовою Книги пам'яті дозволили виявити важливу особливість у реєстрації померлих в області. Попри загальноприйняте уявлення, що завжди вказувалися невідповідні діагнози, були виявлені й діагнози, що прямо зазначали причиною смерті голод. Таких по містах нараховується 75 записів, а в селах - 208.

Ще одним моментом, раніше не зафіксованим дослідниками, було виявлення надзвичайно великої кількості записів, де діагноз не вказувався. В загальній кількості зафіксованих по області смертей вони стоять на першому місці. Ця особливість характерна як для міста, так і для села. У містах, загалом, вони становили 14\%, а в сільській місцевості - 45,9\%. Ця ситуація потребує осмислення. Другу позицію, значно поступаючись першій, займала причина смерті - запалення легенів. У містах $-6,2 \%$, у сільській місцевості - 6,3\%. Третій рядок посідають діагнози, де записано причиною смерті серцеві захворювання. У місті вони склали $6,1 \%$, на селі - 5 \%. Було виявлено, що записувалася ця причина смерті померлим різних вікових категорій, досить часто - дітям. 
Не менш важливим результатом дослідження матеріалів Книги пам'яті стало виявлення такої групи діагнозів, що опосередковано вказують на тодішню трагічну ситуацію в області. Це такі як «виснаження», «слабкість», «набряки», «запалення шлунку», «запалення кишковика», «дизентерія», «отруєння», «інтоксикація», недохарчування, аліментарні набряки, худість, та інші. Ці діагнози фіксувалися як у місті, так і в селах. Це може свідчити про те, що населення області незалежно від місця проживання масово вживало в їжу шкідливі для здоров'я продукти, так звані сурогати, що призводило в кінцевому результаті до смерті. По сільській місцевості таких нами виявлено 10,6\% діагнозів, у містах $-13 \%$.

Таким чином, «Національна книга пам'яті жертв Голодомору 1932-1933 р. Дніпропетровська область», попри неповноту матеріалу, дозволяє виявити загальне та особливе у тогочасній ситуації. По-перше, вона містить тенденції, що не суперечать загальноукраїнським. По-друге, вона переконливо свідчить про те, що голодомор в області лютував як у селах, так і в містах області. Жертвами його були представники всіх національностей та соціальних груп, що мешкали на іiї території. Більшість загиблих становили українці, як основна і найчисельніша національність області, а також росіяни та євреї. Проте на територіях, де більшість становили представники інших національностей, серед померлих більшість становили саме вони. В загальній кількості записів про померлих переважали матеріали, в яких діагноз про причину смерті людини був відсутній. Значний відсоток становили діагнози, що непрямо вказували голод як причину смерті. Малися, хоч і в мінімальній кількості, діагнози, де голод прямо вказувався причиною летального випадку.

\section{БІБІЛІОГРАФІЧНІ ПОСИЛАННЯ}

1. Адміністрвативно-територіальний поділ УСРР. За станом на 1 грудня 1933 р. - Харків, 1933. - С. 6. Режим доступу: http://history.org.ua/LiberUA/AdmTerPod_1933/AdmTerPod_1933.pdf

2. Державний архів Дніпропетровської області. - Ф. 19. - Оп. 1 - Спр. 90.

3. Іваненко В. В. Зміна духовних орієнтирів і соціальної поведінки селянства в умовах суцільної колективізації та голодомору: (на матеріалах Дніпропетровщини) / В. В. Іваненко, Н. Р. Романець // Наддніпрянська Україна. - 2008. - № 6. - 355-363 c.

4. Конквест Р. Жнива скорботи: Радянська колективізація і голодомор / Р. Конквест. - Київ, 1993.

5. Кульчицький С. В. 1) Голодомор 1932-1933 рр. як геноцид: труднощі усвідомлення / С. В. Кульчицький. - Київ, 2008; 2) Історичні зошити: Демографічні наслідки голоду 1933 р. на Україні. Препринт № 4 / С. В. Кульчицький // Академія наук Української РСР. Інститут історії. - Київ, 1989. 3) Ціна «великого перелому» / С. В. Кульчицький. - Київ, 1991.

6. Марочко В. І. 1). Голодомор 1932-1933 pp. / В. І. Марочко. - Київ, 2007. 2) Територія Голодомору $1932-33$ рр. / В. І. Марочко. - Київ, 2014. 3). Територія Голодомору 1932-1933рр. в Україні: етнорегіональний та соціально-демографічний контекст / В. І. Марочко // Голод в Україні у першій половині ХХ століття: причини та наслідки (1921- 1923, 1932-1933, 1946-1947): Матеріали Міжнародної наукової конференції 20-21 листопада 2013 р. Київ, 2013. - С. 99-106.

7. Мейс Д. Політичні причини голодомору в Україні (1932-1933) / Д. Мейс // Студії з україністики: зб. наук. праць [за ред. Р. Радишевського]. - 2004. - № 5. - С. 273-292.

8. Національна книга пам'яті жертв Голодомору 1932-1933 рр. Дніпропетровська область. - Дніпропетровськ, 2008.

9. Нікілєв О. Ф. Трагедія голодомору на Дніпропетровщині: до проблеми демографічних втрат / О. Ф. Нікілєв // Придніпровя: історико-крвєзнавчі дослідження. - 2008. - № 5. - С. 98-102.

10. Романець Н. Р. Демографічні та соціально-економічні наслідки Голодомору 1932-1933 рр. у Дніпропетровській області / Н. Р. Романець // Придніпров’я: історико-краєзнавчі дослідження. - 2008. - № 5. - С. 90-96.

\section{REFERENCES}

1. Administratyvno-terytorial'nyj podil USRR. Za stanom na 1 hrudnia 1933 g. [Administrative territorial division of the USSR. As of December 1, 1933]. (1933). Kharkiv. Retrieved from: http://history.org.ua/LiberUA/AdmTerPod_1933/ AdmTerPod_1933.pdf [in Ukrainian].

2. Derzhavnyj arkhiv Dnipropetrovs 'koi oblasti [State Archives of Dnipropetrovsk region]. F.19, des.1, af. 90 [in Ukrainian]. 
3. Ivanenko, V.V., \& Romanets', N.R. (2008). Zmina dukhovnykh oriientyriv i sotsial'noi povedinky selianstva v umovakh sutsil'noi kolektyvizatsii ta holodomoru: (na materialakh Dnipropetrovschyny) [Change of spiritual reference-points and social behavior of peasantry in the conditions of continuous collectivization and hunger: (on materials of Dnipropetrovsk region]. Naddniprians'ka Ukraina, 6, 355-363 [in Ukrainian].

4. Konkvest, R. (1993). Zhnyva skorboty: Radians'ka kolektyvizatsiia i holodomor [Reaping of sorrow: Soviet collectivization and terror-famine]. Kyjiv [in Ukrainian].

5. Kul'chyts'kyj, S.V. 1). (2008). Holodomor 1932-1933 rr. jak genotsyd: trudnoschi usvidomlennia [Terror-famine 1932 -1933 as a genocide: difficulties of realization] Keiv. 2) (1989). Istorychni zoshyty: Demohrafichni naslidky holodu 1933th. na Ukraini. Preprynt № 4 [The Historical notebooks: the Demographic consequences of hunger in 1933 on Ukraine]. Kyiv: Academies of sciences of Ukrainian SSR. Institute of history. 3) (1991). Tsina "velykoho perelomu» [Cost of «arge break»]. Kyiv [in Ukrainian].

6. Marochko, V.I. 1) (2007). Holodomor 1932-1933 rr. [Terror-famine1932-1933th years]. Kyiv. 2) (2014). Terytoriia Holodomoru 1932-33 rr. [Terytoriia of terror-famine 1932-1933th years]. Kyiv. 3) ( 2013). Terytoriia golodomoru 1932 1933rr. v Ukraini: etnorehional'nyj ta sotsial'no-demohrafichnyj kontekst [The Territory of the Holodomor 1932-1933 in Ukraine: ethno-regional and socio-demographic context]. Holod v Ukraini u pershij polovyni XX stolittia: prychyny ta naslidky (1921-1923, 1932-1933, 1946-1947) - Hunger in Ukraine in the first half of the twentieth century: causes and consequences (1921-1923, 1932-1933, 1946-1947). Proceedings of the International Scientific Conference, (pp. 99106). Kyiv [in Ukrainian].

7. Mejs, D. (2004). Politychni prychyny holodomoru v Ukraini (1932-1933) [Political reasons of terror-famine in Ukraine (1932-1933)]. Studij z ukrajinistycy, 5. R. Radishevsky (Ed.). (pp. 273-292) [in Ukrainian].

8. Natsional'na knyha pam 'iati zhertv Holodomoru 1932-1933 rr. Dnipropetrovs 'ka oblast' [National book of memory of victims of terror-famine 1932-1933 the Dnipropetrovsk area]. (2008). Dnipropetrovsk [in Ukrainian].

9. Nikiljev, O.F. (2008). Trahediia holodomoru na Dnipropetrovschyni:do problemy demohrafichnykh vtrat [A tragedy of terror-famine is on Dnipropetrovs'k area: to problem of demographic losses]. Prydniprovia: istoryko-krajeznavchi doslidzhennja, 5, 98-102 [in Ukrainian].

10. Romanet, N.R. (2008). Demohrafichni ta sotsial'no-ekonomichni naslidky Holodomoru 1932 -1933 rr. u Dnipropetrovs'kij oblasti [Demographic and socio-economic consequences of terror-famine $1932-1933$ in the Dnepropetrovsk area]. Prydniprov'ia: istoryko-kraieznavchi doslidzhennia, 5, 90-96 [in Ukrainian].

\section{Хоменко Наталія Олексіӥвна}

Магістр історії, кафедра історії України

Дніпровський національний університет ім. Олеся Гончара

49000, м. Дніпро, пр. Гагаріна, 72

\section{Khomenko Nataliia}

Master of History, Department of History of Ukraine

Oles Honchar Dnipro National University

72, Gagarina Ave., Dnipro, 49000, Ukraine

Email: natalikhomenko2210@gmail.com

Цитування: Хоменко Н. О. «Національна книга пам’яті жертв Голодомору 1932-1933 рр. Дніпропетровська область»: соціально-демографічний аналіз / Н. О. Хоменко // Науково-теоретичний альманах «Грані». - 2018. - Т. 21. - № 5. - С. 97-102.

Citation: Khomenko, N.O. (2018). «Natsionalna knyha pamiati zhertv Holodomoru 1932-1933 rr. Dnipropetrovska oblast»: sotsialno-demohrafichnyi analiz [«National Book of Memory of Victims of the Holodomor 1932-1933 Dnipropetrovsk Region»: socio-demographic analysis]. Scientific and theoretical almanac «Grani», 21(5), 97-102. 